Play It Again is a section of the journal where we republish quotes, gaffes, and immortal lines from friends and foes of tobacco control. It is compiled by Gene Borio, the webmaster of Tobacco BBS, which is the premier tobacco newsgathering site on the internet. Send contributions (including an original version or photocopy of the sourced item) to him at Tobacco BBS, PO Box 359, Village Station, New York 10014-0359; fax +1001212260 6825. Send quotes from online stories (including the full article) or scanned documents (in GIF or FPEG format), to gborio@mindspring.com

Nicely put: Apt insights from the tobacco control community and others

For our first entry we go back a quarter of a century, and over to the auto industry. Ford's cardiovascular intervention program was meant to encourage its employees to adopt healthier behaviours, like quitting smoking. When Philip Morris heard of the program, a meeting was arranged between the program's coordinator and as high a personage as Dr William L Dunn, who suggested a certain modification. After the meeting, the coordinator wrote to Dunn:

"As to your offer to supply cigarettes to those in the program who find it hard or impossible to quit at reduced prices with varying levels of tar and nicotine, I believe that you have misunderstood the purpose of the program. The intent is not to provide volunteers with alternative ways of maintaining those habits which elevate one's probable risk of heart disease. Our goal is to extinguish such habits.

March 21, 1974. Letter from Donald I Beard, coordinator, cardiovascular intervention program (Ford Motor Company), to Dr William L Dunn, associate principal scientist, Philip Morris, USA. URL:http//www.pmdocs.com/getimg. asp?docid= 1003288771. Source: Anne Landman's Daily Document: Ford Motor Company. "Tobacco BBS" 1999 August 18. URL:http//www.tobacco.org/ Documents/dailydoc/990818ddford.html

In the USA, the powerful libertarian movement espouses a philosophy of laissez faire, with a special focus on "individual responsibility" (but not corporate). The movement has consistently aligned itself on the side of tobacco, despite some serious reservations expressed by icons of the movement like William F Buckley, Barry Goldwater, and Arianna Huffington. The libertarian argument can certainly be seductive, and the industry and its supporters often expound and elaborate on it for their ends. One local councilman, faced with such arguments, had a "choice" rejoinder.

"To me it is a brilliant and evil position for a company to utilise libertarian ideology to keep people enslaved. It is an Orwellian twist to try to make something into a choice that is not a choice. You, sir, are a merchant of death."
Oakland councilman fohn Russo, to "Cigarettes cheaper!" entrepreneur fohn Roscoe. Source: Walker T. New cigarette stores stubbed out in Oakland. "San Francisco Chronicle" 1999 August 10.

"I was reminded to keep the voters in mind several times recently [by pro-smoking factions]. . . But in a sense I can't remember the voters. Because some of the residents protected by this proposal are too young to vote."

Source: Doherty f. Fairhaven passes smoking ban. "Standard-Times" (New Bedford, Massachusetts) 1999 July 27.

$$
\star \star \star
$$

"We don't sell alcohol out of vending machines. They're [tobacco and alcohol] both drugs."

Fudy Knapp of the Minnesota Smoke-Free Coalition. Source: Diaz K. Minneapolis bans most cigarette vending machines. "Minneapolis Star Tribune" 1999 fuly 31.

"Cigarettes with training wheels"

It's unclear where this term, applied to bidis, came from; it has been attributed to unnamed "health authorities" in two recent stories. Sources: Koch W. "USA Today” 1999 Aug 5. Fohnson T. ABC: "Good Morning America" 1999 fune 1.

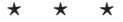

"We've never really had the right comparison group [between smokers and nonsmokers] because everybody has been slightly poisoned."

Dr Rodney Fackson, a professor of epidemiology at the University of Auckland and one of the authors of the ETS/stroke study, published in Tobacco Control 1999;8:156-60. Source: Ross E. Secondhand smoke hikes stroke risk. "AP" 1999 August 17.

"All inhaled smoke is firsthand to the person inhaling."

Source: Barton $\mathcal{F r}, M D R$. Inhaled smoke is firsthand. "Deseret News" August 151999.

Inside the industry

"Maybe you have never dealt with tobacco companies before and you do not know that we keep everything secret here." 
Sergei Kirevnev, a spokesman for Reemstma, the German company that makes West cigarettes, in response to a reporter's questions about a Russian ad. Source: Lally K. Where forbidden is a possibility. "The Baltimore Sun" 1999 fuly 11.

$$
\text { * * * }
$$

"People ask me sometimes, 'How can you operate the largest cigarette company?'. My answer is: I think the most controversial, toughest business requires the best people. ... Good people have the responsibility to do the hard things."

Michael Szymanczyk, chief executive of Philip Morris USA. Source: Lubove S. Smoke this! "Forbes" 1999 August 9.

$$
\star \star \star
$$

“I wouldn't say we debated my decision. . . . But I had to explain the offer I got, and the company. After you sit them down and explain that, they understand that this is what I do."

Stephanie Murray, 24, on explaining her Philip Morris sales job to her Cornell University friends. Source: Wherry R. Reinforcements. "Forbes" 1999 Fuly 26.

\section{The coming storm}

"There have also been a number of adverse legislative, regulatory, political, and other developments concerning cigarette smoking and the tobacco industry that have received widespread media attention. These developments may negatively affect the perception of potential triers of fact with respect to the tobacco industry, possibly to the detriment of certain pending litigation, and may prompt the commencement of additional similar litigation. Management is unable to make a meaningful estimate of the amount or range of loss that could result from an unfavorable outcome of pending litigation."

Source: MO form 10-Q. "Edgar Online” 1999 August 14.

This is a surprisingly ominous statement for a Securities and Exchange Commission filing. The war is, was, and always will be for the hearts and minds of voters and "potential triers of fact"-that is, jurors. Philip Morris recognises this and-before the jury and voter pool becomes even more tainted-is taking strong steps to counteract the recent deluge of bad publicity. Tobacco control advocates should prepare for stigmatisation.

“[Philip Morris' upcoming PR campaign should mean] the most extreme of our critics will be seen by the public as unreasonable.... Hopefully, the demonisation can end or at least fall on increasingly deaf ears, and we will have helped set a positive, enduring course for the future of Philip Morris for many years to come."

Steven C Parrish, Philip Morris'senior vice president for corporate affairs, at a meeting with 450 analysts and investors. Source: Wollenberg S. P Morris expects to miss forecast. "AP" 1999 fune 29.

$$
\star \star \star
$$

"Any kind of allegation like this, especially if true, makes it very difficult for us as an industry to develop a national dialogue about tobacco."

Steve Parrish, vice president and lawyer at Philip Morris. The judge and a plaintiff's lawyer in the Butler secondhand smoke case have filed separate lawsuits claiming that tobacco company lawyers conspired with a phone company employee (who was the lawyer's ex-husband) to access their personal and business telephone records. Source: Curriden M. Attorney, judge suing tobacco firm. “Dallas Morning News” 1999 August 8.

"We take the view that smoking is an adult pastime. We don't like kids smoking, we don't think it's right, but equally it's not good for our image."

Martin Broughton, British American Tobacco (BAT) chairman. Source: Gledhill D. BAT urges higher smoking age. "The Independent" 1999 August 8.

$$
\star \star \star \star
$$

"As well as wanting to be the world leader in the tobacco business, I would also like to see a general perception of us as a responsible company. I would like it to be said that we are reputable people, that there is a consumer demand out there, and it is better that it is provided for by us than by smugglers or bootleggers."

Martin Broughton, BAT chairman. Source: Gledhill D. The tobacco roadrunnner. "The Independent” 1999 August 8.

\section{Industry science}

"I think it's a risk factor. I think it's a contributing factor. But certainly from a scientific factor, the answer has to be no."

Richard D Thomas, a scientist formerly with the National Academy of Sciences who testified for tobacco in the Gilboy trial, when asked after court if smoking causes lung cancer. Source: Baughman C. Smoke tests on animals said negative. "Baton Rouge (LA) Advocate” 1999 Fuly 7.

"The results show that ammonia treatment caused a general increase in the delivery of bases including a $29 \%$ increase in nicotine. ... In other words, the nicotine transfer has increased as a result of ammonia treatment."

1965 document from BAT, part of the ASH/ICRF/Massachusetts report. Source: Reane P. Chemicals increase smoking's grip-report. "Reuters" 1999 fuly 14.

$$
\star \star \star
$$

"Is Scott Appleton's [B\&W's director of scientific and regulatory affairs] current practice regarding information about scientific developments adequate? Among other considerations, should he attend conferences normally attended by a toxicologist? ... What answer do you recommend for Mr Sandefur when asked how he knows causation has not been proven?"

1993 letter in which BEWW counsel F Kendrick Wells asks for some lawyerly advice from Shook 
Hardy's Northrip and Kirk E Spalding's Gordon A Smith. Source: How does BEW know about the science? "Tobacco BBS" 1999 August 14. URL:http//www.tobacco.org/Documents/931123 bwwells.html

"I think this is a scandal — the idea that you could take a cigarette and make it more addictive while at the same time you are publicly denying that nicotine is addictive at all... Without telling anyone, they (tobacco companies) have been free basing nicotine and engineering subtle changes to the brain chemistry of the smoker."

Clive Bates, the director of ASH London, on the ASH/ICRF/Massachusetts report on internal tobacco industry documents about the use of additives. Source: Additives make cigarettes more addictive—report. "Reuters" 1999 Fuly 14.

"Targacept is totally separate and apart from our cigarette business. . . We're not doing any work in Targacept with an eye to applying any of it to our cigarette business."

Spokesman Seth Moskowitz, on RFR's new unit Targacept, which will compete with the pharmaceutical giants to develop a new class of powerful drugs known as nicotinic compounds. Source: Hwang S. Rf Reynolds hopes to spin nicotine knowledge into drugs. "The Wall Street Fournal Interactive Edition” 1999 Fune 28.

On the battlefield: quotes from the front "That's what happens. They attack us, and we attack them. And you know who gets lost in the middle? The business owners trying to make a living. And that's too bad."

Eric Schippers, senior vice president of the National Smokers' Alliance (NSA), who fails to note that what really gets lost are the health issues that spark legislation - an excellent benefit to having groups like the NSA around to create a commotion. Source: Doherty f. Smoking lobby meets its match/local foes have backing for long battle. "Standard-Times" (New Bedford, Massachusetts) 1999 August 1.

$$
\star \star \star \star
$$

'Because the National Smokers' Alliance is no longer in alignment with the values and beliefs that guide the conduct of business at Philip Morris, henceforth we will be withdrawing all of our financial support from the organisation."

Ellen Merlo, senior vice president, corporate affairs, Philip Morris USA. Source: Philip Morris USA withdraws support for National Smokers Alliance/condemns personal attack on senator McCain. "Business Wire” 1999 June 29.

The tobacco control movement

"We have always learned that the farther we get from the ground the better chance we have of defeating a proposal. ...At the level of the town meeting, we are almost always killed. At the board of health level, we do better. At the city council level, we do very well. And at the state level, we do great."
October 1994 internal Tobacco Institute document. The reporter quoted this document as just another piece of source material (in a story on Massachusetts' tobacco control politics). This may presage a new, more casual but trenchant way of using the Minnesota documents. Source: Phillips F. On politics. State's finding on smoking ban ignites debate. "The Boston Globe” 1999 fuly 26.

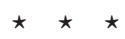

"This is the best grass roots lobbying group the world has ever seen."

Bruce Potter, of the Massachusetts Restaurant Association, on the Massachusetts Department of Health's tobacco control program. Source: Dohert 7. Smoking ban a triumph for grass roots group. "Standard-Times" (New Bedford, Massachusetts) 1999 July 20.

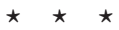

"[WHO] has extraordinary influence on government and consumers and we must find a way to diffuse this and reorient their activities to their prescribed mandate. In addition, we need to think through how we could use our food companies, size, technology, and capability with governments by helping them with their food problems and give us a more balanced profile with the government than we now have against WHO's powerful influence."

Geoffrey Bible in a 1988 Philip Morris document, memorandum from employee to counsel and employee discussing industry response to surgeon general's report. URL: http//www. tobaccodocuments.com/raw/dispPage.cfm? Search Key $=$ forest $\% 20$ and $\% 20$ smokers $\mathcal{E}$ HideComment $=$ YESED DisplayFormat $=G I F \mathcal{E}$ parentID $=26806$ Source: "Tobacco BBS" 1999 fuly 29. URL: http/l www. tobacco.org/Documents/881201biblewho.html

\section{International}

"It concerns me that safeguards we consider vital in the West are not thought necessary for people in the developing world ... [where some ads are] an obvious evil, at best indiscriminate, and at worst targeted at children."

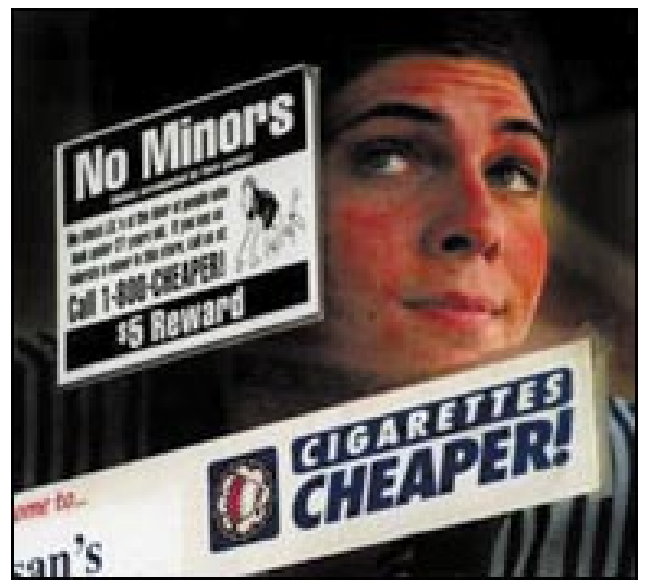

Seventeen year old Paul Rhatigan successfully bought cigarettes in a "sting" operation at an Arizona Cheaper Cigarettes store: he then called the toll free (freephone) number to turn in the clerk, promptly collected Cheaper Cigarettes's \$5 reward - a gift certificate- and then used the certificate to "purchase" cigarettes in a second "sting". 


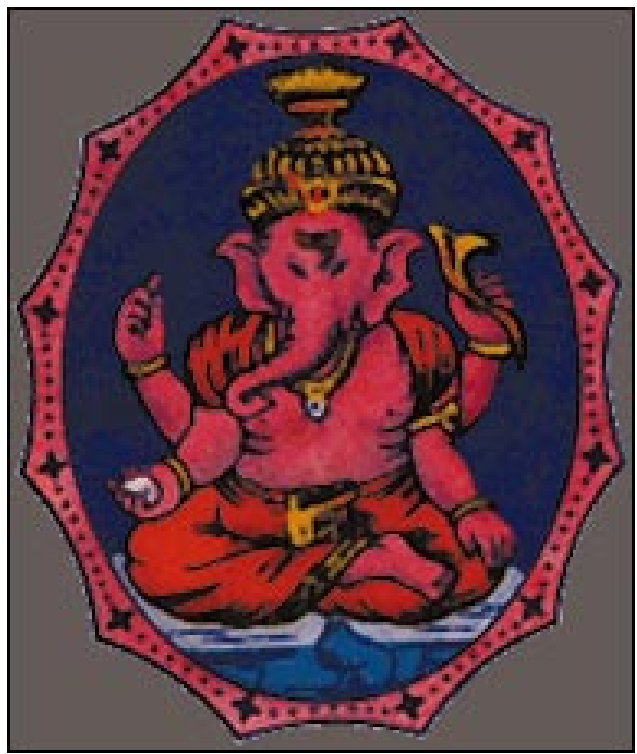

Symbol of Indian god for Ganesh Bidis. On November 24, 1999, the import of Mangalore Bidi Works'products was banned by US Customs Service director Ray Kelly - the day after a TV program exposed child labour conditions in the company's cigarette factories.

British shadow international development secretary Gary Streeter, in a letter to Martin Broughton, the chief executive of BAT. The attack was backed by some prominent Tory leaders. Source: Newton P. Tories attack "evil" tobacco ads. "Electronic Telegraph"1999 fuly 19.

"It's almost like a Third World revenge. While the US dumps cigarettes into Third World countries, we have India dumping bidis here."

Greg Connolly, director of the Massachusetts Department of Public Health's tobacco control program. Source: Squires S. Imported cigarettes draw teens, criticism. "The Washington Post" 1999 August 17.

"The bidi sector offers work to such a large number of people. ... We have to make sure it keeps going."

SK Das, director general of the Maharashtra Labor Ministry, which has twice backed down from a state order to raise bidi-roller wages. Source: Fordan M. Behind a hot smoke, hard labor: women toil to supply bidi cigarette. "The Wall Street Fournal Interactive Edition” 1999 August 17.

"In other countries, cigarette smoking is cultural."

Roy Betts, a US postal service spokesman, explaining that an ad for its worldwide delivery service that featured a woman smoking was meant for an international audience. The ad was terminated after an uproar in the United States. Source: Burkins G. Cigarette in a postal service ad burns up some critics of smoking. "Wall Street Fournal" 1999 August 25.

$$
\star \star \star
$$

"Our stance is that consumers should gauge for themselves the risks involved in smoking, so

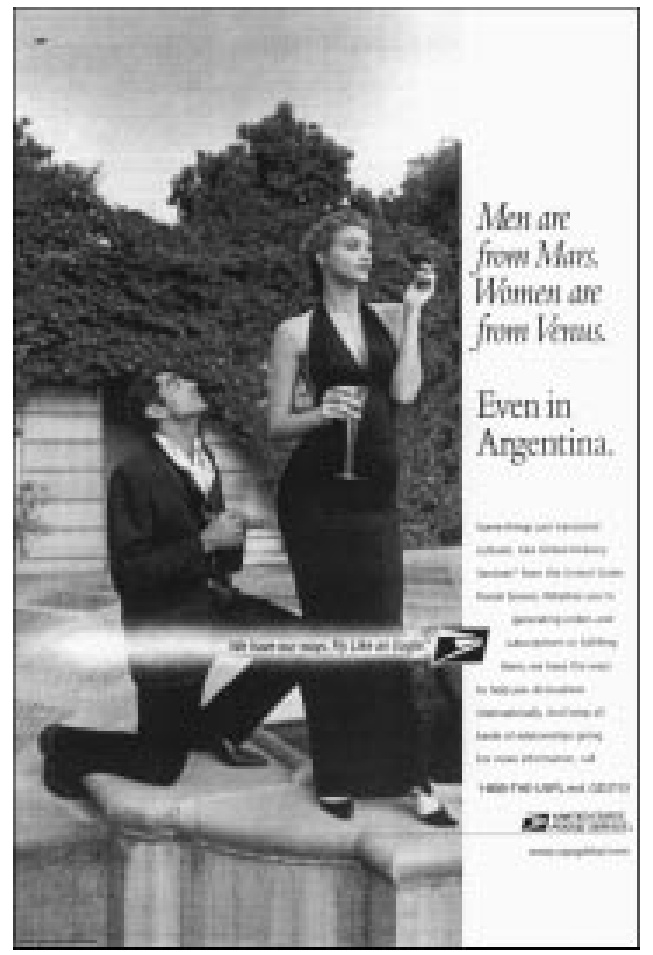

US postal service ad, featuring a woman smoking.

we asked that the panel reconsider those proposals."

Unidentified fapan Tobacco spokesman, on a draft of the Health and Welfare Ministry's proposal to seek a 50\% reduction in tobacco use by 2010. Source: Kim C. Fapan unveils plan to reduce cigarette consumption. "The Wall Street fournal Interactive Edition” 1999 August 12.

\section{Kerala}

The state of Kerala on India's western shore passed an unprecedented-and fully enforced-total ban on smoking in public places.

"After three weeks of the judicial crackdown on smokers, the tobacco industry in Kerala has reported a $30 \%$ drop in the sale of cigarettes, bidis, and similar products."

Unidentified senior industry ministry official in Kerala, on the state's heavily enforced ban on smoking in all public places. Source: Iype G. Smoking ban leaves Kerala treasury gasping. "Rediff on the Net" 1999 August 3.

"The police are forced to apprehend as many people as possible. . . . The actual number of smokers held by the police throughout the state is not available. However, the unofficial estimates put the number of those caught by the police in the past one week at more than 4000."

Source: Fose D. Kerala court ban on cigarettes ignites industry anger. "Rediff on the Net" 1999 Fuly 29.

\section{US settlement}

The US states' attorney general settlement with the industry has created an uncomfortable alliance unique in history. 
"The creative projects that you and others have developed for your state to use these [settlement] funds will be cut back, perhaps sharply."

Letter to their peers from five tobacco state governors warning of the dire effects of -horrors! - a reduction in smoking rates if prices rise because of a successful federal lawsuit against tobacco. Source: Mitchel K. Tobacco state governors ask peers to oppose suit. "Winston-Salem fournal" 1999 August 7.

"Advertising has really been the No 1 accomplice in selling smoking. ... We have had a shameful role in this for a long time, so I'm excited about us as an industry trying to fix what we did wrong."

Alex Bogusky, partner and creative director at Crispin Porter \& Bogusky in Coral Gables, Florida. Source: Elliot S. Advertising: Ad sellers switch sides, unselling the cigarette. "New York Times" 1999 August 2.

$$
\star \star \star
$$

"I don't want to be a partner with the tobacco industry."

Colorado treasurer Mike Coffman, who has proposed selling off the state's share of the tobacco settlement. Source: Soraghan M. Upfront tobacco payout sought. "Denver Post” 1999 Fuly 20.

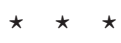

"The tobacco companies duped the AGs, who had no idea what they were doing. . . . The net result of this agreement is that the tobacco companies will make even more money because they are in a protected market.”

Matthew Fairshter, an international trade, copyright and corporate attorney who is also preparing an antitrust complaint on behalf of several discount cigarette distributors. Source: Fried $R$. Distributors challenging tobacco deal/growing tide of suits allege that settlement between the government and big tobacco is anti-competitive. "Callaw/The Recorder" 1999 Fune 30.

Fads

"Cigarettes kill you. Cigars smell bad. Pipes make you look smart."

Watts Wacker, a Connecticut futurist who studies tobacco trends. Ebnet M. A "nice vice"/pipes are making a comeback. Some say it's because they're viewed as a laid back, less harmful way to "look smart”. "Los Angeles Times” 1999 fune 29.

\section{Lawsuits}

"[Cigarette makers] engaged in extreme and outrageous conduct . . . [made] false or misleading statements . . . [conspired to] misrepresent information relating the health effects of cigarette smoking ... [acted with] reckless disregard."

Some jury findings in the Florida Engle trial. Source: Kidwell D, Merzer M. Cigarette foes win Florida suit/verdict finds tobacco industry lied, concealed health effects. "St Paul (Minnesota) Pioneer Press" 1999 fuly 8.
"As a former smoker with a heart condition, [Judge Kaye] is potentially part of the [Engle] class and that makes him unsuitable."

BAT chairman Martin Broughton, on the industry's motion to remove Dade County circuit judge Robert Kaye from the Engle trial. Source: Pylas P. Tobacco industry seeks to oust judge with heart problem. "The Wall Street fournal Interactive Edition” 1999 August 3.

"For Lakota people, an eagle feather is earned when an individual accomplishes a deed of great courage and valour. . . . On behalf of the Lakota people, I am extremely offended by the image of Joe Camel wearing eagle feathers."

Oglala Sioux president Harold Salway. Tobacco marketing to native youth by RFR and American Spirit is examined. Source: Taliman V. The tobacco wars ignite. "Indian Country Today"1999 fune 28.

"In the absence of any realistic plan for managing the proposed class action, in the absence of any realistic showing that a large increase in judicial resources would become available to handle the thousands of individual, complex tort cases that a class action would splinter into ... this court cannot find that the superiority criterion has been satisfied.

Fustice Nathan L Berke of Queens County supreme court, in refusing to certify the Geiger class action. Source: Riccardi M. Class action status denied in NY tobacco case. "Law News Network" 1999 fuly 8.

"Our position is that the (product) packages don't fulfill the requirements of proposition 65 in that it's not a clear and reasonable warning to those who aren't consumers of tobacco."

Los Angeles deputy city attorney Amy Sopuch. Attorneys for California are seeking a court order that would require tobacco companies to pay for television, radio and newspaper ads warning of health risks to non-smokers from secondhand smoke. Source: Philip Morris. Others asked to give non-smokers clear warnings. "Bloomberg News" 1999 August 11.

"[India's] statutory warning regime is shamelessly flouted by tobacco companies, which resort to every possible measure to make the warning inconspicuous, including resorting to surrogate advertising and brand stretching."

Senior advocate Indira faisingh, before India's supreme court. Source: Kalra A. SC slaps notices on cigarette majors for non-compliance with statutory warnings. "Indian Express" 1999 August 10.

\section{Teens}

"They should provide us with new lungs. .. .We all smoke, and by the time we grow old, we're going to need them."

Seventeen year old Pauline Lawson, on what to do with tobacco settlement monies. Source: Schogol $M$, Bolling D, Carroll E. With billions of dollars on table, ideas abound. "Philadelphia Inquirer" 1999 Fuly 30 . 
"I think it's surprising how widespread DARE is, given the lack of hard data suggesting it is effective."

Donald $R$ Lynam, whose University of Kentucky study found the 10 year old, disputed DARE program ineffective. This is interesting when you compare DARE's perennial financial backing (sans independent verification of its effectiveness) with the intense scrutiny Florida legislators demanded of the successful TRUTH program. Source: Ritchie f. New study on drug education program. "AP" 1999 August 3.

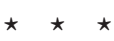

"We could get thrown out of school for this."

"I can't. A friend's coming over and I have to get home to meet him."

"Anybody want to go to a movie?"

Some proposed responses to teen peer pressure to smoke, offered by RfR. Source: Tobacco: helping your child say no! "Right decisions right now" (RFRT) 1999 fuly 17.

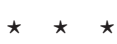

"The strategy is fairly simple: 1 . Heavily promote industry opposition to youth smoking. 2 . Align industry with broader, more sophisticated view of the problem-that is, parental inability to offset peer pressure. 3. Work with and through credible child welfare professionals and educators to tackle the 'problem'. 4. Bait anti-tobacco forces to criticise industry efforts. . . . Contingency planning helps us anticipate and counter antis' claims. For example, TI might conduct its own 'sting' operation to demonstrate (a) that it took us 25 'stings' to find our first 'It's the law' violation, and (b) that the industry is attempting to enforce its own code."

Fan 29, 1991 Tobacco Institute "discussion paper" on the industry's youth program. URL: http//www.tobaccoinstitute.com/getimg. asp?pgno= $0 \mathcal{E}$ start $=0$ E bool $=$ TIMN0164422/4424. Source: Tobacco Institute "discussion paper" on the industry's youth program. "Tobacco BBS" 1999 fuly 14. URL: http//www.tobacco.org/Documents/ 910129TI MNO164422ythpgm.html

\section{Society}

"At 70, I'm in fine fettle for my age, sleep like a babe and feel around 12. The secret? Lots of meat, drink, and cigarettes and not giving in to things."

UK TV chef Fennifer Paterson, who died of lung cancer aged 71. Source: One fab lady/TV chef Fennifer loses cancer battle at 71. "The Mirror" 1999 August 11.
"I take a short break just long enough to have a cigarette every couple of hours."

Emil Morton, an Edmonton fringe festival "static mime" who for up to 10 hours a day can withstand taunts, bathroom needs, his hair on fire-everything but his need for nicotine. Source: Eckler R. Not even bare breasts can make him blink. "National Post" 1999 August 16.

\section{$\star \star \star \star$}

"We get lots of families in here. The first thing we ask them is, 'smoking or nonsmoking?'. And it's the parents' choice where they want their kids to sit."

Fanet Parmer, co-owner of Loca Luna in Little Rock. Source: Sandlin F. LR restaurants get 15 days to designate smoke-free sections. "Arkansas Democrat-Gazette” 1999 August 19.

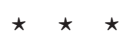

"I don't have a vision for the city of tens of thousands of ashtrays."

San Francisco supervisor Gavin Newsom, whose holdings include two restaurants and a wine shop. Source: Epstein E. Butt of course, SF passes ashtray law/businesses must provide receptacles outside their doors. "San Francisco Chronicle" 1999 fuly 27.

\section{Out of the past}

Some quotes were noteworthy simply because of who said them:

"I think it is absurd to worry about small amounts of pesticides on tobacco leaves. . . . There is no safe use of tobacco-whether you are smoking it, chewing it, whether it is in a pipe or a cigar.

Seminal Environmental Protection Agency report critic Michael Fumento, who is now a health writer at the Hudson Institute, on the US Department of Agriculture report which found domestically banned pesticides in foreign tobaccos. Source: Saffir B. Official seeks tobacco import tests. "Washington Times"1999 August 17.

"There were pacts made between the devil and the unimaginable. . . [The industry PR campaign's] intent was to create disinformation."

Tobacco scientist Gary Huber surfaces again in the UK's "Tobacco Wars" documentary. Source: Smoke screen: why governments have succumbed as easily as youngsters to the power of the tobacco industry. "The Independent via NewsEdge" 1999 fuly 27. 